\title{
Chemotactic activity of cerebrospinal fluid in pyogenic meningitis
}

\author{
B. M. GREENWOOD \\ From the Department of Medicine, Ahmadu Bello University, Zaria, Nigeria
}

SUMMARY Cerebrospinal fluid from patients with pyogenic meningitis was found to be chemotactic for polymorphonuclear neutrophil leucocytes. No significant difference was found between the mean chemotactic activity of cerebrospinal fluid obtained from patients with pneumococcal meningitis or meningococcal meningitis. The chemotactic factor present in cerebrospinal fluid is probably a low molecular weight protein, perhaps a complement component.

The mortality from pneumococcal meningitis remains distressingly high, especially in the tropics (Baird et al., 1976), despite treatment with high doses of antibiotics to which the pneumococcus is very susceptible in vitro. Penicillin enters the cerebrospinal fluid (CSF) in bactericidal concentrations (Bunn and Peabody, 1952) and should be able to destroy bacteria present in the subarachnoid space. However, it has been shown (Wood and Smith, 1956) that bacteria in a stationary phase of growth are relatively resistant to the action of penicillin. In this situation polymorphonuclear neutrophil leucocytes within the subarachnoid space probably play an important part in overcoming the infection. Little is known about the factors influencing the movement of polymorphonuclear neutrophil leucocytes into the subarachnoid space or about the effects of CSF on their function. In this study I have shown the presence of a chemotactic factor for polymorphonuclear nuetrophil leucocytes in the CSF of patients with pneumococcal and meningococcal meningitis.

\section{Patients and methods}

PATIENTS

Fifty adult patients with pyogenic meningitis admitted consecutively to Ahmadu Bello University Teaching Hospital, Zaria, Nigeria, during the period January to April 1975 were studied. Fifteen patients had pneumococcal meningitis, 13 group A meningococcal meningitis, and 22 group $\mathrm{C}$ meningococcal meningitis. Diagnosis was made by a positive CSF culture or by the detection of capsular polysaccharide antigen in the CSF. Control CSF samples were

Received for publication 10 August 1977 obtained from patients whose clinical picture suggested a possible diagnosis of meningitis but whose CSF was subsequently found to be normal.

\section{METHODS}

\section{Routine CSF examination}

Cerebrospinal fluid was collected into heparin or dipotassium ethylenediaminetetra-acetic acid (EDTA) immediately after admission of the patient to hospital and before the start of treatment. Cell and bacterial counts were made within a short time of collection. Typing was achieved by direct countercurrent immunoelectrophoresis of CSF against group and type specific antisera. Protein was estimated by the method of Lowry et al. (1951). C3 was measured by radial immunodiffusion using a pooled normal Nigerian plasma sample as standard.

\section{Measurement of chemotaxis}

Chemotaxis was studied using a tuberculin syringe technique (Wilkinson, 1974). One-millilitre plastic syringes were cut through at the $0 \cdot 2-\mathrm{ml}$ mark and a $3-\mu$ filter (Millipore SSWP 01300) was glued to the bottom with an alcohol soluble glue (Uhu, Fishmar). Syringes were prepared the night before use and tested for leaks before being loaded.

Blood from a healthy adult was collected in heparin and mixed with an equal volume of $3 \%$ dextran, and the mixture was allowed to sediment. The same donor was used throughout the study. The leucocyte-rich plasma fraction was centrifuged and the cell button obtained was washed twice in Hanks' solution supplemented with $1 \%$ fetal calf serum. The cell button was then made up in a small volume of Hanks' solution without fetal calf serum, and the 
polymorphonuclear neutrophil leucocytes present were counted and made up to a final concentration of $5 \times 10^{9} / 1$. Centrifugation and washing were carried out at room temperature to prevent leucocyte aggregation. Endotoxin free glassware was used throughout.

A $0.2 \mathrm{ml}$ aliquot of the leucocyte suspension was added to each tuberculin syringe, and the syringes were suspended in a glass test tube containing test or control solutions. Care was taken to see that the fluid levels within and without the syringe were identical. The tubes were incubated for three hours at $37^{\circ} \mathrm{C}$. After incubation the top and bottom of each filter were carefully washed with saline and the filter was then dissolved away from the bottom of the syringe by immersion in $70 \%$ alcohol. Filters were stained with Harris haematoxylin, mounted in Eukitt medium and examined upside down for the number of polymorphonuclear neutrophil leucocytes that had migrated through the disc. The number of cells per high-power field $(\times 40)$ in the first field of focus was recorded. At least five fields were examined and the mean count was determined.

Cerebrospinal fluid samples were centrifuged shortly after collection, and the supernatant was removed and stored at $-20^{\circ} \mathrm{C}$ until tested. For the chemotactic assay CSF was diluted $1: 2$ in Hanks' solution. A positive control was used in each assay. This was made by adding $1 \mathrm{ml}$ of a solution of Escherichia coli 0127 B4 endotoxin (Difco), at a concentration of $300 \mu \mathrm{g} / \mathrm{ml}$, to $1 \mathrm{ml}$ of fresh serum and $8 \mathrm{ml}$ of Hanks' solution. The mixture was incubated for one hour at $37^{\circ} \mathrm{C}$ and then inactivated by incubation at $56^{\circ} \mathrm{C}$ for 30 minutes.

Duplicate samples in the same assay showed variations within the range of $\pm 20 \%$. More marked variation was seen between assays despite the fact that the same donor cells were used throughout the study. Leucocyte counts of 3-10 cells per high-power field were obtained in tissue culture medium control tubes while endotoxin gave counts of $150-350$ cells per high-power field. In an attempt to correct for this variation the chemotactic activity of test samples has been expressed as a chemotactic index $=$ the number of cells per high-power field in the test sample - the number of cells per high-power field in the tissue culture medium control $\div$ the number of cells per high-power field in the endotoxin sample - the number of cells per high-power field in the tissue culture medium control $\times 100 \%$.

\section{Characterisation of the chemotactic factor}

Pooled CSF samples were tested for chemotactic activity after heating to $56^{\circ} \mathrm{C}$ for 30 minutes and $100^{\circ} \mathrm{C}$ for five minutes. Dialysis was carried out in Visking tubing with a pore size of approximately 10000 daltons. Pooled samples were incubated with 0 trypsin at a final concentration of $0.5 \%$ for $24 \vec{\circ}$

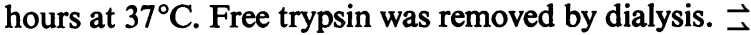
A control sample was incubated under identical $\omega$ conditions with tissue culture medium alone. Gel filtration was carried out on Sephadex G 50 and G 25 using Hanks' solution as the eluant. Pooled samples were incubated overnight at $4^{\circ} \mathrm{C}$ with a $1 \cdot 10$ solution of antisera to $\mathrm{C} 3, \mathrm{C} 3$ breakdown $\vec{\omega}$ products, C4, and factor B (Hyland Laboratories and Dutch Red Cross Blood Transfusion Laboratories, Amsterdam).

\section{Results}

ROUTINE CSF FINDINGS

The results of CSF cell count, bacterial count, protein, and C3 determinations on the samples used in this study are shown in Table 1 . The mean bacterial count in the CSF of patients with pneumococcal meningitis was significantly higher than the mean bacterial count in the CSF of patients with meningococcal meningitis $(P<0.001)$ but other findings were $\bar{O}$ similar.

CHEMOTACTIC ACTIVITY OF CSF

Ten samples of normal CSF showed no chemotactic activity. In contrast CSF from nearly all patients $:$ with pneumococcal or meningococcal meningitis was chemotactic (Fig. 1). No significant difference was $ᄋ$ found between the chemotactic activity of CSF from patients with pneumococcal or meningococcal 을 meningitis or between the CSF of patient with group A or group $\mathbf{C}$ meningococcal meningitis. Results from patients with the two types of meningococcal meningitis have therefore been pooled in Figure 1.

CORRELATION OF CSF CHEMOTACTIC ACTIVITY WITH OTHER FINDINGS The results of correlation of CSF chemotactic

Table 1 Cerebrospinal fluid cell and bacterial counts, protein, and C3 levels in 50 patients with pyogenic meningitis (mean $\pm 1 S D$ )

\begin{tabular}{|c|c|c|c|c|}
\hline Type of meningitis & Cell count $\times 10^{\circ} / l$ & Bacterial count $\times 10^{\circ} \%$ & Protein $(\mathrm{g} / \mathrm{l})$ & C3 $\%$ standard \\
\hline $\begin{array}{l}\text { Pneumococcal }(n=15) \\
\text { Meningococcal A }(n=13) \\
\text { Meningococcal C }(n=22)\end{array}$ & $\begin{array}{r}7.8 \pm 18 \cdot 8 \\
11.4 \pm 11.9 \\
8.6 \pm 6.9\end{array}$ & $\begin{array}{r}146 \pm 186 \\
14 \pm 19 \\
26 \pm 28\end{array}$ & $\begin{array}{l}6.6 \pm 4.6 \\
6.0 \pm 4 \cdot 2 \\
3.9 \pm 2 \cdot 1\end{array}$ & $\begin{array}{r}14.5 \pm 17 \cdot 1 \\
12.9 \pm 11 \cdot 0 \\
5.6 \pm 5.9\end{array}$ \\
\hline
\end{tabular}




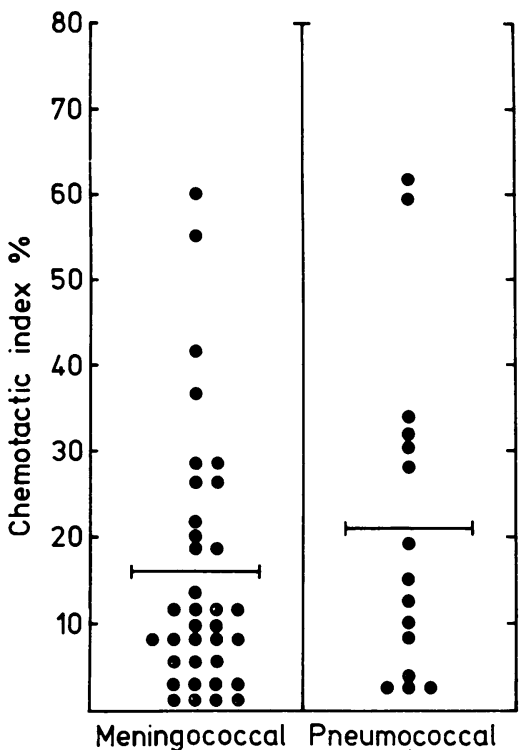

Fig. 1 Chemotactic activity of cerebrospinal fluid obtained from patients with pneumococcal or meningococcal meningitis.

activity with other CSF findings are shown in Table 2. Chemotactic activity was correlated significantly with CSF protein and C3 levels in patients with both pneumococcal and meningococcal meningitis. In patients with pneumococcal meningitis it was also correlated with CSF bacterial counts. No correlation with CSF cell count was found.

Eight of the 15 patients with pneumococcal meningitis died. Their mean chemotactic index $(26 \% \pm 25 \%)$ did not differ significantly from that of the survivors $(16 \% \pm 11 \%)$. Six of the patients with pneumococcal infection had a type 1 infection. Their mean chemotactic index $(24 \% \pm 11 \%)$ was similar to that of patients with other types of pneumococcal infection $(22 \% \pm 25 \%)$.

Table 2 Correlation of CSF chemotactic activity with other CSF findings

\begin{tabular}{llll}
\hline & $\begin{array}{l}\text { Pneumococcal } \\
(n=15)\end{array}$ & $\begin{array}{l}\text { Meningococcal } \\
(n=35)\end{array}$ & $\begin{array}{l}\text { Total } \\
(n=50)\end{array}$ \\
\hline Cell count & $\mathrm{r}=0.26$ & $\mathbf{r}=0.08$ & $\mathrm{r}=0.19$ \\
Bacterial count & $\mathrm{r}=0.82^{*}$ & $\mathrm{r}=-0.04$ & $\mathrm{r}=0.20$ \\
Protein & $\mathrm{r}=0.48^{*}$ & $\mathrm{r}=0.58^{*}$ & $\mathrm{r}=0.55^{*}$ \\
C3 & $\mathrm{r}=0.81^{*}$ & $\mathrm{r}=0.53^{*}$ & $\mathrm{r}=0.65^{*}$ \\
\hline
\end{tabular}

*Correlation coefficient statistically significant.

NATURE OF CHEMOTACTIC FACTOR

No difference was found in the properties of the chemotactic factor found in the CSF of patients with pneumococcal or meningococcal meningitis. The results of heating, trypsin digestion, and dialysis are shown in Table 3. Addition of fresh serum to CSF considerably enhanced its chemotactic activity but EDTA plasma did not. Attempts were made to neutralise the chemotactic factor present in CSF by incubation with various anticomplement sera. The results of these experiments were inconclusive as many of the antisera used were themselves chemotactic.

The results of fractionation of a pneumococcal CSF pool on Sephadex G 50 are shown in Figure 2. Most activity was found in the fraction eluting after albumin. In a further experiment using Sephadex G 25 activity was found over a wide range extending from the end of the CSF protein peak to the peak of an insulin marker (MW approximately 6000). Similar results were obtained with a meningococcal CSF pool.

Table 3 Effects of heating, dialysis, and trypsin digestion on CSF chemotactic activity. Results, which are expressed as the percentage change in chemotactic index, are the mean of three experiments

$\%$ Change in chemotactic index

\begin{tabular}{ll}
\hline Heating to $56^{\circ} \mathrm{C}$ for $30 \mathrm{~min}$ & +14 \\
Heating to $100^{\circ} \mathrm{C}$ for $5 \mathrm{~min}$ & -89 \\
Dialysis & +84 \\
Trypsin digestion & -100
\end{tabular}

Trypsin digestion $\quad-100$

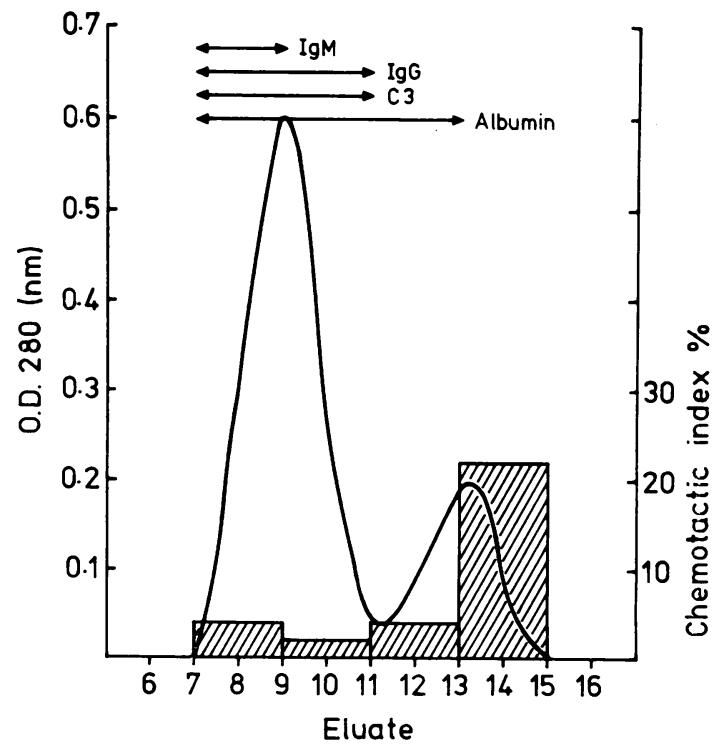

Fig. 2 Fractionation of a CSF pool from patients with pneumococcal meningitis on Sephadex $G 50$ showing chemotactic activity in the low molecular weight protein fraction. 


\section{Discussion}

This study has shown that the CSF of most patients with pneumococcal or meningococcal meningitis is chemotactic for polymorphonuclear neutrophil leucocytes. Heating, digestion, and fractionation experiments suggest that the active factor or factors are proteins with molecular weights between 10000 and 80000 daltons. Chemotactic activity correlated closely with CSF levels of $\mathrm{C} 3$, suggesting that the chemotactic factor might be a complement component, perhaps C5a. Some indirect support for this view was provided by the finding that both meningococcal and pneumococcal CSF could generate chemotactic activity in fresh serum but not in EDTA plasma. Binding of a chemotactic peptide to albumin could account for the fact that activity was found over a wide range on Sephadex fractionation. Meningococcal endotoxin and pneumococcal capsular polysaccharide, can readily be detected in the CSF of patients with meningococcal or pneumococcal meningitis and both can activate the alternative complement pathway. However, the results of incubation of CSF with anticomplement antisera were inconclusive and further experiments are required before it can be concluded that the chemotactic factor present in CSF is a complement component. My findings are thus in agreement with those of a recent experimental study by Nolan $e t$ al. (1975), who found a chemotactic factor in the CSF of rabbits with pneumococcal meningitis. This factor was also thought to be a low molecular weight protein, perhaps a complement component, but this could not be proven.

Pneumococcal meningitis has a much higher mortality than meningococcal meningitis. The reasons for this difference are incompletely understood. The finding of low CSF white cell counts in many patients with pneumococcal meningitis who subsequently died (Quaade and Kristensen, 1962; Tugwell et al., 1976) suggested to us that defective function of CSF polymorphonuclear neutrophil leucocytes might be one of the factors contributing to the high mortality of this infection. The possibility that the low CSF white cell count found in some patients with pneumococcal meningitis was due to defective CSF chemotaxis was considered but the results of this study do not support this hypothesis. No difference was found between the chemotactic activity of CSF from patients with pneumococcal or meningococcal meningitis and no correlation was found between the cell count and chemotactic activity of individual samples. In another study (Greenwood, unpublished) I have shown that although CSF samples from many patients with pyogenic meningitis contain a potent leucocidin this factor is unlikely be responsible for the low CSF white cell count found in some patients with pneumococcal meningitis. The cause of this phenomenon remains to be resolved.

I thank my colleagues Dr H. C. Whittle and Dr I. I. Onyewotu for their help with this study. I am supported by the UK Medical Research Council.

\section{Referenses}

Baird, D. R., Whittle, H. C., and Greenwood, B. M (1976). Mortality from pneumococcal meningitis. Lancet, 2, 1344-1346.

Bunn, P. A., and Peabody, G. (1952). Treatment of pneumococcal meningitis with large doses of penicillin; series of 20 consecutive cases. Archives of Internal Medicine, 89, 736-742.

Lowry, O. H., Rosebrough, N. J., Farr, A. L., and Randall, R. J. (1951). Protein measurement with the folin phenol reagent. Journal of Biological Chemistry, 193, 265-275.

Nolan, C. M., Clark, R. A., and Beaty, H. N. (1975). Experimental pneumococcal meningitis: III. Chemotactic activity in cerebrospinal fluid. Proceedings of the Society of Experimental Biology and Medicine, 150, 134-136.

Quaade, F., and Kristensen, K. P. (1962). Purulent meningitis. A review of 658 cases. Acta Medica Scandinavica, 171, 543-550.

Tugwell, P., Greenwood, B. M., and Warrell, D. A. (1976). Pneumococcal meningitis: a clinical and laboratory study. Quarterly Journal of Medicine, 45, 583-601.

Wilkinson, P. C. (1974). Chemotaxis and Inflammation, 을 pp. 168-172. Churchill Livingstone, Edinburgh and $\mathrm{N}$ London.

Wood, W. B., and Smith, M. R. (1956). An experimental N analysis of the curative action of penicillin in acute $N$ bacterial infections, I. Relationship of bacterial growth rates to the antimicrobial effect of penicillin. Journal of Experimental Medicine, 103, 487-498. 